\title{
Hubungan Faktor Risiko dengan Tingkat Depresi pada Gay, Transgender, dan LSL
}

\author{
Resati Nando Panonsih ${ }^{1}$, Ika Artini ${ }^{2}$, Arif Effendi ${ }^{3}$, Aradhea Kumala Azizah ${ }^{4}$ \\ ${ }^{1)}$ Departemen Dermatologi dan Venereologi RS Pertamina Bintang Amin, dr_r3sati@yahoo.com \\ ${ }^{2}$ Departemen Farmakologi Fakultas Kedokteran Universitas Malahayati, ikaartini@malahayati.ac.id \\ ${ }^{3}$ Departemen Dermatologi dan Venereologi RS Abdul Moeloek, arif.effendi62@yahoo.com \\ 4)Program studi kedokteran Fakultas Kedokteran Universitas Malahayati, aradheakml@gmail.com
}

\begin{abstract}
ABSTRAK
Masalah kesehatan yang dialami gay, transgender, dan LSL (Lelaki Seks dengan Lelaki) salah satunya masalah psikologi seperti depresi. Masalah sosial yang sering dialami mereka adalah stigma dan diskriminasi, termasuk akses ke pelayanan kesehatan. Faktor risiko depresi antara lain keturunan, usia, dan faktor psikososial. Penelitian ini bertujuan untuk mengetahui hubungan faktor risiko depresi dengan tingkat keparahan depresi pada gay, transgender, dan LSL di Bandar Lampung tahun 2019. Jenis penelitian ini bersifat survei analitik secara cross sectional. Pengambilan sampel ini dilakukan dengan menggunakan total sampling. Responden dalam penelitian ini adalah anggota Organisasi Gaya Lentera Muda Bandar Lampung sebanyak 35 orang. Jenis data yang diperoleh yaitu data primer. Hasil penelitian menunjukkan dari 35 responden didapatkan bahwa responden dengan pendidikan menengah sebagian besar mengalami depresi ringan sebanyak 7 responden (36,8\%). Responden dengan status bekerja sebagian besar mengalami depresi ringan sebanyak 6 responden (33,3\%). Responden yang memiliki faktor keturunan sebagian besar mengalami depresi berat sebanyak 13 responden (72,2\%). Terdapat hubungan bermakna antara faktor keturunan ( $p$ value $=0,000$ ) dan faktor psikososial (tingkat pendidikan $p$ value $=0,040$ dan status pekerjaan $p$ value $=0,050)$ dengan tingkat keparahan depresi pada gay, transgender, dan LSL(Lelaki Seks dengan Lelaki). Tidak terdapat hubungan bermakna antara faktor usia ( $p$ value $=0,856)$ dengan tingkat keparahan depresi pada gay, transgender, dan LSL(Lelaki Seks Lelaki).
\end{abstract}

Kata kunci: Depresi, Gay, Transgender, LSL

\section{ABSTRACT}

Health problems experienced by gay, transgender, and MSM (Men who have Sex with Men) one of the psychological problems such as depression. The social problems that they often experience are stigma and discrimination, including access to health services. The risk factors of depression are genetic, age, and psychosocial factors. This study conducted to determine the relationship between risk factors of depression with levels of depression to the gay, transgender, and MSM in Bandar Lampung 2019. Methods: The type of research is an analytic survey with a cross-sectional. The samples were taken using total sampling. The subjects in this research are all 35 members of the Gaya Lentera Muda Organization. The type of data obtained is primary data. The results of this research that from 35 subjects is obtained the subjects with middle education mostly have mild depression of 7 subjects $(36,8 \%)$. The subjects who have an occupation mostly have mild depression of 6 subjects $(33,3 \%)$. The subjects who have genetic factors mostly have severe depression of 13 subjects $(72,2 \%)$. There is a meaningful relationship between genetic factor ( $p$ value $=0,000$ ) and psychosocial factor (education level $p$ value $=0,040$ and employment status $p$ value $=0,050$ ) with levels of depression to the gay, transgender, and MSM (Men who have Sex with Men). There is no relationship between age factor ( $p$ value $=0,856$ ) with levels of depression to the gay, transgender, and MSM (Men who have Sex with Men).

Keywords: Depression, Gay, Transgender, MSM

* Korespondensi Author: Resati Nando Panonsih, Departemen Dermatologi dan Venereologi Rumah Sakit Pertamina Bintang Amin,dr_r3sati@yahoo.com, Telp.081227766689

\section{PENDAHULUAN}

Gay merupakan seorang laki-laki yang menyukai dan juga mencintai laki-laki. ${ }^{1}$ Lelaki Seks dengan Lelaki (LSL) merupakan laki-laki yang berhubungan seksual dengan laki-laki lainnya, tanpa memandang orientasi seksualnya atau identitas gender. ${ }^{2}$ Transgender merupakan istilah identitas diri untuk mendeskripsikan 
orang yang berpikir, melakukan, merasa atau terlihat berbeda dari jenis kelamin yang ditetapkan saat mereka lahir. ${ }^{3}$

Masalah kesehatan yang dialami gay, transgender, dan LSL (Lelaki Seks Lelaki) salah satunya masalah psikologi seperti depresi. Masalah sosial yang sering dialami mereka adalah stigma dan diskriminasi, termasuk akses ke pelayanan kesehatan. ${ }^{4}$ Suatu gangguan suasana perasaan (mood) yang memiliki gejala utama afek depresi, hilangnya minat dan kegembiraan, kekurangan energi seperti mudah lelah, dan menurunnya aktivitas disebut depresi. Faktor risiko depresi antara lain gangguan dari neurotransmitter, faktor keturunan (genetik) yaitu riwayat keluarga mengalami depresi, faktor usia yaitu usia $\leq 40$ tahun berisiko mengalami depresi, dan faktor psikososial yaitu peristiwa hidup dan lingkungan sosial yang membuat stres seperti tingkat pendidikan yang rendah dan status pekerjaan yang buruk. Ketidakmampuan untuk menerima diri menyebabkan berbagai kesulitan emosi seperti kemarahan dan depresi. ${ }^{5}$

Penelitian internasional di Spanyol menyatakan bahwa tingkat depresi lebih tinggi pada remaja gay, transgender, dan LSL (Lelaki Seks Lelaki) dibandingkan dengan remaja heteroseksual, karena mereka merasakan bahwa posisi mereka adalah minoritas dan dapat menimbulkan kecemasan sosial. ${ }^{6}$ Hasil penelitian Pratiwi dkk tahun 2014 di Surakarta menyatakan sebanyak 10 responden gay $(32,3 \%)$ mengalami depresi ringan, 9 responden gay (29\%) mengalami depresi sedang, 6 responden gay (19,4\%) mengalami depresi berat dan 6 responden gay $(19,4 \%)$ yang tidak mengalami depresi. ${ }^{5}$ Hasil penelitian Mariany dkk tahun 2019 di Kota Pematangsiantar, komunitas LSL lebih banyak mengalami depresi sebanyak 19 orang $(59,4 \%)$ dan tidak depresi sebanyak 13 orang (40,5\%). ${ }^{7}$ Survei National Center for Transgender Equality tahun 2015, bahwa 39\% menderita tekanan psikologis serius salah satunya depresi dari 27.715 transgender. ${ }^{8}$

Menurut Estimasi Kementrian Kesehatan Republik Indonesia (KemenKes RI) tahun 2012 terdapat 1.095.970 LSL (Lelaki Seks
Lelaki) ${ }^{1}$. Jumlah gay di Indonesia diperkirakan 3.000.000 orang pada tahun 2012. ${ }^{9}$ Jumlah transgender tahun 2010 di 33 provinsi di Indonesia sebanyak 31.179 jiwa. $^{10}$ Gay, transgender, dan LSL (Lelaki Seks Lelaki) di Bandar Lampung tergabung dalam sebuah organisasi dengan nama Gaya Lentera Muda Lampung (Gaylam). Hasil pre-survei yang dilakukan pada hari Jumat, 4 Oktober 2019 didapatkan data jumlah pengurus dan anggota organisasi Gaylam Bandar Lampung sebanyak 30-35 orang.

Dengan demikian, berdasarkan uraian latar belakang diatas, peneliti tertarik untuk melakukan penelitian mengenai hubungan faktor risiko depresi dengan tingkat keparahan depresi pada gay, transgender, dan LSL (Lelaki Seks Lelaki). Penelitian ini penting karena untuk mengetahui faktor risiko apa yang paling dominan mempengaruhi tingkat depresi pada gay, transgender, dan LSL (Lelaki Seks Lelaki) di Organisasi Gaylam Bandar Lampung. Data yang telah dijelaskan mendukung pemilihan kota Bandar Lampung sebagai spesifikasi tempat penelitian. Permasalahan dalam penelitian ini adalah mencari hubungan faktor risiko depresi meliputi faktor usia, psikososial (tingkat pendidikan dan status pekerjaan) dan keturunan dengan tingkat keparahan depresi pada gay, transgender, dan LSL (Lelaki Seks Lelaki) di Bandar Lampung Tahun 2019.

\section{METODOLOGI}

Penelitian ini menggunakan pendekatan kuantitatif bersifat survei analitik secara cross sectional, dimana peneliti mencari tahu hubungan faktor risiko depresi dengan tingkat keparahan depresi pada gay, transgender, dan LSL di Bandar Lampung Tahun 2019. Penelitian ini dilaksanakan pada bulan September sampai November 2019. Populasi dalam penelitian ini adalah seluruh anggota Organisasi Gaylam Bandar Lampung sebanyak 35 orang. Sampel pada penelitian ini diambil dengan menggunakan tekhnik total sampling yaitu jumlah sampel sama dengan populasi yaitu 35 orang. 
Alat ukur yang digunakan untuk variabel independen yaitu faktor risiko depresi diukur dengan kuesioner demografi, sedangkan untuk variabel dependen yaitu tingkat keparahan depresi diukur dengan Skala Nilai Depresi Hamilton.Data penelitian diolah dengan program SPSS dengan menggunakan analisis univariat untuk menjabarkan tabel distribusi variabel penelitian, kemudian dilanjutkan analisis bivariat dengan uji korelasi Spearman untuk mengetahui hubungan faktor risiko depresi dengan tingkat keparahan depresi. Pengujian analisis dengan tingkat kesalahan 5\% apabila didapatkan nilai $\mathrm{p} \leq 0,05$ maka Ho ditolak, dan $\mathrm{Ha}$ diterima yaitu terdapat hubungan bermakna antara dua variabel yang diuji.

\section{HASIL DAN PEMBAHASAN}

\section{Analisis Univariat}

Tabel 1. Distribusi Tingkat Keparahan Depresi pada Gay, Transgender, dan LSL

\begin{tabular}{ccc}
\hline Tingkat Depresi & Frekuensi & $\begin{array}{c}\text { Persentase } \\
(\%)\end{array}$ \\
\hline Depresi Berat & 13 & 37,1 \\
Depresi Sedang & 5 & 14,3 \\
Depresi Ringan & 9 & 25,7 \\
Normal & 8 & 22,9 \\
\hline Total & 35 & 100 \\
\hline
\end{tabular}

Berdasarkan tabel 1 di atas bahwa dari 35 responden didapatkan distribusi tingkat keparahan depresi paling banyak depresi berat sebanyak 13 responden $(37,1 \%)$, kemudian depresi ringan sebanyak 9 responden $(25,7 \%)$, normal sebanyak 8 responden $(22,9 \%)$, dan depresi sedang sebanyak 5 responden (14,3\%).

Tabel 2. Distribusi Usia, Tingkat Penddikan, Status Pekerjaan, dan Faktor Keturunan Depresi pada Gay, Transgender, dan LSL

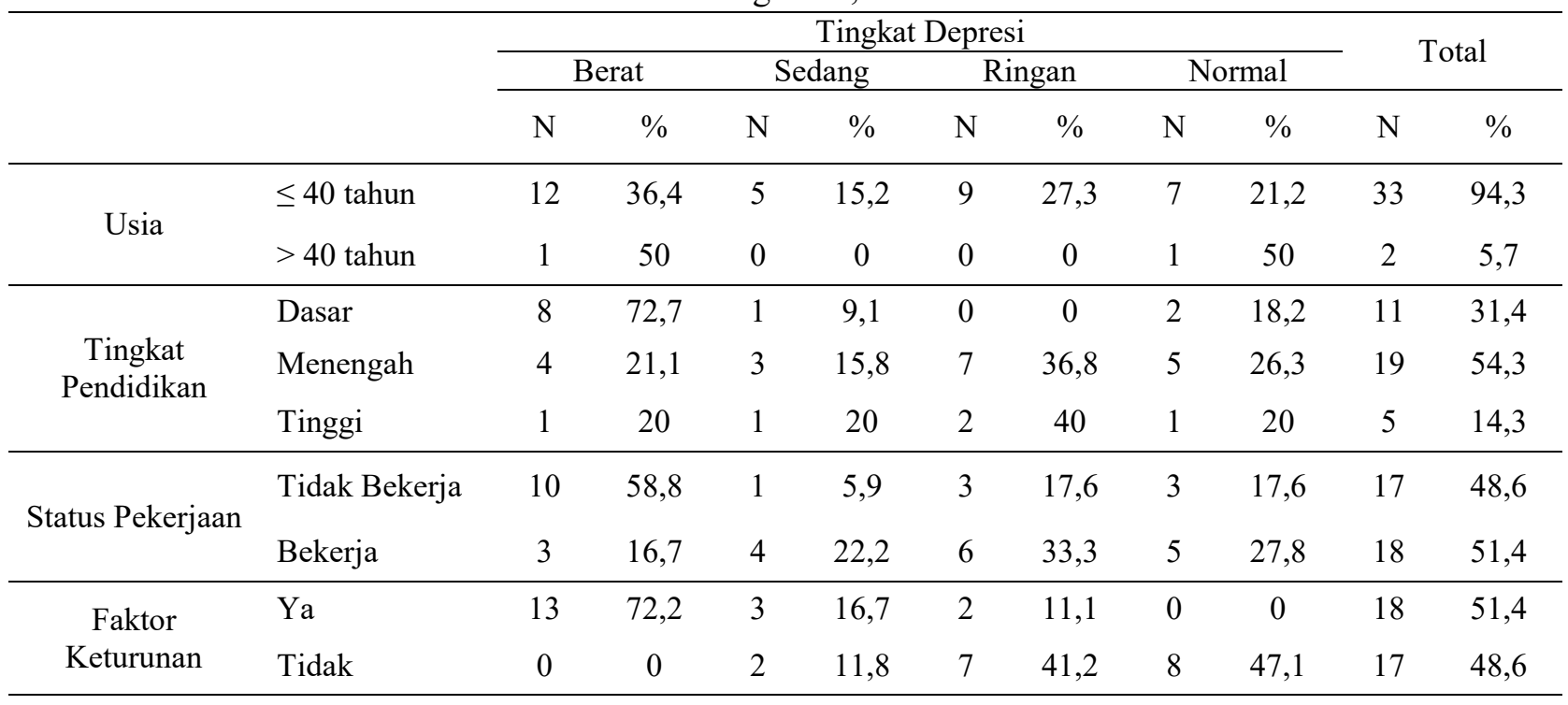


Berdasarkan tabel 2 di atas bahwa dari 35 responden didapatkan distribusi usia responden paling banyak kelompok usia $\leq 40$ tahun sebanyak 33 responden $(94,3 \%)$ dengan tingkat depresi berat sebanyak 12 responden $(36,4 \%)$, depresi ringan sebanyak 9 responden $(27,3 \%)$, normal sebanyak 7 responden $(21,2 \%)$, dan depresi sedang sebanyak 5 responden $(15,2 \%)$. Distribusi tingkat pendidikan paling banyak pendidikan menengah sebanyak 19 responden $(54,3 \%)$ dengan tingkat depresi ringan sebanyak 7 responden $(36,8 \%)$, normal sebanyak 5 responden $(26,3 \%)$, depresi berat sebanyak 4 responden $(21,1 \%)$, dan depresi sedang sebanyak 3 responden $(15,8 \%)$. Distribusi status pekerjaan paling banyak status bekerja sebanyak 18 responden $(51,4 \%)$ dengan tingkat depresi ringan sebanyak 6 responden $(33,3 \%)$, normal sebanyak 5 responden $(27,8 \%)$, depresi sedang sebanyak 4 responden $(22,2 \%)$, dan depresi berat sebanyak 3 responden (16,7\%). Distribusi faktor keturunan paling banyak yaitu responden yang memiliki faktor keturunan sebanyak 18 responden $(51,4 \%)$ dengan tingkat depresi berat sebanyak 13 responden $(72,2 \%)$, depresi sedang sebanyak 3 responden $(16,7 \%)$, dan depresi ringan sebanyak 2 responden $(11,1 \%)$.

\section{Analisis Bivariat}

Tabel 3. Uji Korelasi Spearman Hubungan Faktor Risiko Depresi dengan Tingkat Keparahan Depresi pada Gay, Transgender, dan LSL

\begin{tabular}{|c|c|c|c|c|c|c|c|c|c|c|c|c|c|}
\hline & \multicolumn{8}{|c|}{ Tingkat Depresi } & \multirow{2}{*}{\multicolumn{2}{|c|}{ Total }} & \multirow{3}{*}{$P$} & \multirow{3}{*}{$r$} \\
\hline & & \multicolumn{2}{|c|}{ Berat } & \multicolumn{2}{|c|}{ Sedang } & \multicolumn{2}{|c|}{ Ringan } & \multicolumn{2}{|c|}{ Normal } & & & & \\
\hline & & $\mathrm{N}$ & $\%$ & $\mathrm{~N}$ & $\%$ & $\mathrm{~N}$ & $\%$ & $\mathrm{~N}$ & $\%$ & $\mathrm{~N}$ & $\%$ & & \\
\hline \multirow{2}{*}{ Usia } & $\leq 40$ tahun & 12 & 36,4 & 5 & 15,2 & 9 & 27,3 & 7 & 21,2 & 33 & 94,3 & \multirow{2}{*}{0,856} & \multirow{2}{*}{$-0,032$} \\
\hline & $>40$ tahun & 1 & 50 & 0 & 0 & 0 & 0 & 1 & 50 & 2 & 5,7 & & \\
\hline \multirow{3}{*}{ Tingkat Pendidikan } & Dasar & 8 & 72,7 & 1 & 9,1 & 0 & 0 & 2 & 18,2 & 11 & 31,4 & \multirow{3}{*}{0,040} & \multirow{3}{*}{$-0,349$} \\
\hline & Menengah & 4 & 21,1 & 3 & 15,8 & 7 & 36,8 & 5 & 26,3 & 19 & 54,3 & & \\
\hline & Tinggi & 1 & 20 & 1 & 20 & 2 & 40 & 1 & 20 & 5 & 14,3 & & \\
\hline \multirow{2}{*}{ Status Pekerjaan } & Tidak Bekerja & 10 & 58,8 & 1 & 5,9 & 3 & 17,6 & 3 & 17,6 & 17 & 48,6 & \multirow{2}{*}{0,050} & \multirow{2}{*}{$-0,334$} \\
\hline & Bekerja & 3 & 16,7 & 4 & 22,2 & 6 & 33,3 & 5 & 27,8 & 18 & 51,4 & & \\
\hline \multirow{2}{*}{ Faktor Keturunan } & Ya & 13 & 72,2 & 3 & 16,7 & 2 & 11,1 & 0 & 0 & 18 & 51,4 & \multirow{2}{*}{0,000} & \multirow{2}{*}{$-0,821$} \\
\hline & Tidak & 0 & 0 & 2 & 11,8 & 7 & 41,2 & 8 & 47,1 & 17 & 48,6 & & \\
\hline
\end{tabular}

Berdasarkan tabel 3 di atas bahwa hasil analisis uji Spearman dengan tingkat kesalahan $5 \%$ didapatkan faktor usia dengan nilai $\mathrm{p}=$ $0,856$ ( $\mathrm{p}>0,05)$ menunjukkan bahwa Ho diterima yang artinya tidak terdapat hubungan yang bermakna antara faktor usia dengan tingkat keparahan depresi pada gay, transgender, dan LSL di Bandar Lampung tahun 2019. Nilai koefisien korelasi sebesar -0,032 menunjukkan hampir tidak ada kekuatan korelasi dan bersifat negatif.

Faktor psikososial yaitu tingkat pendidikan dengan nilai $\mathrm{p}=0,040(\mathrm{p} \leq 0,05)$ menunjukkan bahwa Ho ditolak yang artinya terdapat hubungan yang bermakna antara tingkat pendidikan dengan tingkat keparahan depresi pada gay, transgender dan LSL di Bandar Lampung tahun 2019. Nilai koefisien korelasi sebesar -0,349 menunjukkan kekuatan korelasi rendah dan bersifat negatif dan status pekerjaan dengan nilai $\mathrm{p}=0,050(\mathrm{p} \leq 0,05)$ menunjukkan bahwa Ho ditolak yang artinya terdapat hubungan yang bermakna antara status pekerjaan dengan tingkat keparahan depresi pada gay, transgender dan LSL di Bandar Lampung tahun 2019. Nilai koefisien korelasi 
sebesar -0,334 menunjukkan kekuatan korelasi rendah dan bersifat negatif.

Selanjutnya, faktor keturunan dengan nilai $\mathrm{p}=0,000(\mathrm{p} \leq 0,05)$ menunjukkan bahwa Ho ditolak yang artinya terdapat hubungan yang bermakna antara faktor keturunan dengan tingkat keparahan depresi pada gay, transgender dan LSL di Bandar Lampung tahun 2019. Nilai koefisien korelasi sebesar -0,821. Artinya, menunjukkan kekuatan korelasi sempurna dan bersifat negatif.

\section{Hubungan Faktor Usia dengan Tingkat Keparahan Depresi}

Berdasarkan hasil tabel 3 menunjukkan bahwa hasil analisis uji Spearman faktor usia didapatkan nilai $\mathrm{p}=0,856(\mathrm{p}>0,05)$ dan nilai koefisien korelasi $r=-0,032$ disimpulkan bahwa tidak terdapat hubungan bermakna antara faktor usia dengan tingkat keparahan depresi pada subjek penelitian. Hasil penelitian ini sesuai dengan penelitian yang dilakukan oleh Suwistianisa dkk tahun $2015(p=0,949)$ dan Dudung dkk tahun $2015(p=0,235)$ bahwa tidak ada hubungan yang bermakna antara usia dengan tingkat depresi. ${ }^{11,12}$ Hasil penelitian ini didapatkan bahwa orang yang berusia $\leq 40$ tahun ternyata masih ada yang tidak mengalami depresi. Hal ini disebabkan pada rentang usia tersebut terdapat faktor lingkungan yang dapat mencetuskannya. Jika tidak ada faktor yang mencetuskannya selain faktor usia, depresi belum tentu terjadi pada gay, transgender, dan LSL. Rentang usia depresi tersebut berpengaruh pada kasus depresi pada seseorang dimana dapat disebabkan karena adanya perbedaan hormonal dan perbedaan stressor psikososial. ${ }^{13}$

\section{Hubungan Faktor Psikososial dengan Tingkat Keparahan Depresi}

Berdasarkan hasil tabel 3 menunjukkan bahwa hasil analisis uji Spearman tingkat pendidikan didapatkan nilai $p=0,040(p \leq 0,05)$ dan nilai koefisien korelasi sebesar $r=-0,349$ disimpulkan bahwa terdapat hubungan bermakna antara tingkat pendidikan dengan tingkat keparahan depresi pada subjek penelitian. Hasil penelitian ini sesuai dengan penelitian yang dilakukan oleh Fatmawati dkk tahun $2017(p=0,033)$ dan penelitian Sativa tahun $2015(p=0,001)$ bahwa terdapat hubungan yang bermakna antara tingkat pendidikan dengan tingkat depresi. ${ }^{14,15}$ Dalam pendidikan, salah satu masalah kelompok gay, transgender, dan LSL adalah penerimaan diri dari orientasi seksualnya. Tingkat penerimaan diri mereka mempengaruhi pada aspek-aspek kepribadiannya. Khususnya di lingkungan sekolah atau kampus, mereka mendapat perlakuan yang tidak baik seperti bullying dari teman-temannya ataupun tenaga pendidik sehingga mereka tidak ingin melanjutkan pendidikannya. ${ }^{16}$

Selanjutnya, status pekerjaan dengan nilai $p=0,050(p \leq 0,05)$ dan nilai koefisien korelasi sebesar $r=0,334$ disimpulkan bahwa terdapat hubungan bermakna antara status pekerjaan dengan tingkat keparahan depresi pada subjek penelitian. Hasil penelitian ini sesuai dengan penelitian yang dilakukan oleh Fatmawati dkk tahun $2017(p=0,004)$ dan Palizgir dkk tahun $2013(p=0,000)$ bahwa terdapat hubungan yang bermakna antara status pekerjaan dengan tingkat depresi. ${ }^{14,17}$

Tingkat depresi dapat dipengaruhi oleh rendahnya aktivitas fisik dan kegiatan yang dilakukan responden yang tidak bekerja. Responden yang tidak bekerja cenderung tidak memiliki aktivitas yang teratur dan lebih banyak berdiam diri di rumah sehingga mengurangi interaksi sosial terhadap lingkungan. Interaksi sosial yang kurang dapat memicu depresi karena dapat menyebabkan tidak adanya dukungan dan komunikasi dari lingkungan. ${ }^{17}$ Kelompok LSL kesulitan mendapatkan pekerjaan karena menderita HIV, dimana masyarakat di lingkungannya menilai mereka tidak baik, mereka dipisahkan dan diasingkan dari masyarakat. $^{7}$

\section{Hubungan Faktor Keturunan dengan Tingkat Keparahan Depresi}

Berdasarkan hasil tabel 3 menunjukkan bahwa hasil analisis uji Spearman faktor keturunan didapatkan nilai $p=0,000(p \leq 0,05)$ dan nilai koefisien korelasi sebesar $r=0,821$ 
disimpulkan bahwa terdapat hubungan bermakna antara faktor keturunan dengan tingkat keparahan depresi pada subjek penelitian. Hasil penelitian ini sesuai dengan penelitian yang dilakukan oleh Wahyuningsih tahun 2015 bahwa terdapat hubungan yang bermakna antara faktor keturunan dengan tingkat depresi pada pasien gangguan jiwa di desa Banaran Galur Kulor Progo Yogyakarta ( $p$ $=0,007)$ dengan ditinjau dari kedekatan riwayatnya, riwayat keturunan depresi tersebut berasal langsung dari ibunya. ${ }^{18}$ Hasil ini sesuai juga dengan penelitian Yanuar tahun 2012 yang juga menemukan dominasi individu dengan gangguan jiwa dengan faktor keturunan gangguan jiwa di Desa Paringan, Kecamatan Jenangan, Kabupaten Ponorogo $(p=0,03)$. Hasil tersebut menunjukkan gangguan jiwa depresi lebih banyak terjadi pada responden yang memiliki faktor keturunan gangguan jiwa depresi. ${ }^{19}$

Sesuai dengan teori Sadock bahwa memiliki orang tua yang menderita depresi berhubungan dengan tingginya tingkat depresi pada anak-anak. Kemungkinan mengalami gangguan mood berkurang jika derajat hubungan keluarga menjauh. ${ }^{20}$ Penyebab orang tua bisa mengalami depresi bermacam-macam seperti masalah kesehatan dan lingkungan, salah satunya memiliki anak yang berperilaku homoseksual. Menurut penelitian Kircher dan Ahlijah tahun 2011, respon awal orang tua setelah mengetahui bahwa anaknya seorang homoseksual berupa perasaan marah dan sedih. Hal ini karena orang tua menyadari bahwa anaknya tidak akan mampu menjalani kehidupan sebagai seorang heteroseksual dan sesuai dengan norma sosial yang berlaku di masyarakat. ${ }^{21}$

\section{SIMPULAN DAN SARAN}

Berdasarkan hasil dan pembahasan penelitian tentang hubungan faktor risiko depresi dengan tingkat keparahan depresi pada gay, transgender, dan LSL (Lelaki Seks Lelaki) di Bandar Lampung Tahun 2019, dapat disimpulkan bahwa:

1. Diketahui sebagian besar distribusi tingkat keparahan depresi pada gay, transgender, dan
LSL (Lelaki Seks Lelaki) di Bandar Lampung tahun 2019 adalah depresi berat sebanyak 13 responden $(37,1 \%)$.

2. Diketahui sebagian besar distribusi usia pada gay, transgender, dan LSL (Lelaki Seks Lelaki) di Bandar Lampung tahun 2019 adalah usia $\leq$ 40 tahun sebanyak 33 responden $(94,3 \%)$.

3. Diketahui sebagian besar distribusi tingkat pendidikan pada gay, transgender, dan LSL (Lelaki Seks Lelaki) di Bandar Lampung tahun 2019 adalah pendidikan menengah sebanyak 19 responden $(54,3 \%)$.

4. Diketahui sebagian besar distribusi status pekerjaan pada gay, transgender, dan LSL di Bandar Lampung tahun 2019 adalah status bekerja sebanyak 18 responden $(51,4 \%)$.

5. Diketahui sebagian besar distribusi faktor keturunan depresi pada gay, transgender, dan LSL (Lelaki Seks Lelaki) di Bandar Lampung tahun 2019 adalah responden yang memiliki keturunan sebanyak 18 responden $(51,4 \%)$.

6. Diketahui terdapat hubungan bermakna antara faktor keturunan dan faktor psikososial dengan tingkat keparahan depresi pada gay, transgender, dan LSL (Lelaki Seks Lelaki) di Bandar Lampung tahun 2019 dengan nilai $p$ value $=0,000(p \leq 0,05) r=-$ 0,821 (faktor keturunan), $\mathrm{p}$ value $=0,040(\mathrm{p}$ $\leq 0,05) \mathrm{r}=-0,349$ (tingkat pendidikan), dan $\mathrm{p}$ value $=0,050(\mathrm{p} \leq 0,05) \mathrm{r}=-0,334$ (status pekerjaan). Dapat disimpulkan bahwa semakin baik tingkat pendidikan dan status pekerjaan maka semakin ringan tingkat keparahan depresi dan seseorang yang memiliki derajat hubungan keluarga yang dekat yaitu orang tua yang sedang atau pernah mengalami depresi maka semakin berat tingkat keparahan depresi. Selanjutnya, tidak terdapat hubungan bermakna antara faktor usia dengan tingkat keparahan depresi pada gay, transgender, dan LSL (Lelaki Seks Lelaki) di Bandar Lampung tahun 2019 dengan nilai $\mathrm{p}$ value $=0,856(\mathrm{p}>0,05) \mathrm{r}=$ 0,032 .

Hasil penelitian ini diharapkan dapat dijadikan acuan pengetahuan tentang hubungan faktor risiko depresi dengan tingkat keparahan depresi pada gay, transgender, dan LSL (Lelaki 
Seks Lelaki). Diharapkan pula agar dapat melakukan penelitian dengan jumlah sampel yang lebih banyak.

\section{UCAPAN TERIMA KASIH}

Peneliti mengucapkan terima kasih kepada tuhan Yang Maha Esa yang telah memberikan rahmat dan pertolongannya sehingga penelitian ini dapat berjalan dengan lancar. Peneliti juga mengucapkan terima kasih kepada semua pihak yang berperan dalam pelaksanaan penelitian ini, terutama kepada pengurus dan anggota Organisasi Gaylam Bandar Lampung.

\section{REFERENSI}

1. KemenSos RI. Meluasnya LGBT (Lesbian, Gay, Biseksual, dan Transgender) akibat Lemahnya Sosial Kontrol Masyarakat. Jakarta: Badan Pendidikan dan Penelitian Kesejahteraan Sosial; 2016.

2. KemenKes RI. Pedoman Nasional Penanganan Infeksi Menular Seksual 2016. Jakarta: Kementerian Kesehatan Republik Indonesia; 2016.

3. Yanuarti, E. Pola Asuh Islami Orang Tua dalam Mencegah Timbulnya Perilaku LGBT sejak Usia Dini. J Cendekia. 2019; 17 (1): 64-5.

4. Tama, A. Peran United Nations Development Programme (UNDP) dalam Melegalkan Pernikahan lesbian,Gay,Bisexual,Transgender ( LGBT ) di Tiongkok. J Online Mahasiswa. 2017; 4 (2): 7.

5. Pratiwi, N. A., Suwito, D., dan Hikmayani, N. H. Hubungan antara Penerimaan diri dan Depresi pada Komunitas Gay di Surakarta. Nexus Kedokteran Komunitas. 2014; 3 (1): 93.

6. Jose, P. E., Alexandra, M., Mireia, O., dan Rafael, B. Autoconcepto, ansiedad social y sintomatología depresiva en adolescentes Españoles según su orientación sexual. $J$ of Ansiedad y Estrés. 2012; 18 (1): 31-41.

7. Mariany, B. S., Asfriyati, dan Sanusi, S. R. Stigma Depresi, dan Kualitas Hidup Penderita HIV: Studi pada Komunitas "Lelaki Seks dengan Lelaki"di Pematangsiantar. Berita Kedokteran Masyarakat. 2019; 35 (4): 139-46.

8. James, S. E., Herman, J. L., Rankin S., Keisling, M., Mottet, L., dan Anafi, M.. The Report of the 2015 U.S. Transgender Survey. Washington, DC: National Center for Transgender Equality; 2016.
9. Yudianto. Fenomena Lesbi, Gay, Biseksual, dan Transgender (LGBT) di Indonesia serta Upaya Pencegahannya, NIHZAM. 2016; 5 (1): 63-73.

10. KemenSos RI. Kementerian Sosial dalam Angka Pembagunan Kesejahteraan Sosial. Jakarta: Badan Pendidikan dan Penelitian Kesejahteraan Sosial; 2012.

11. Suwistianisa, R., Huda, N., dan Ernawaty, J. Faktor-Faktor yang Mempengaruhi Tingkat Depresi pada Pasien Kanker yang Dirawat di RSUD Arifin Achmad Provinsi Riau. J Online Mahasiswa. 2015; 2 (2): 1463-73.

12. Dudung, J., Kaunang, T.M.D., dan Dundu, A.E. Prevalensi Depresi pada Pasien Stroke yang di Rawat Inap di Irina F RSUP Prof. Dr. R. D. Kandou Manado Periode November Desember 2012. J e-Clinic. 2015; 3 (1): 577.

13. Yaunin, Y., Afriant, R., dan Hidayat, N. M. Kejadian Gangguan Depresi pada Penderita HIV/AIDS yang Mengunjungi Poli VCT RSUP Dr. M. Djamil Padang Periode Januari September 2013. Artikel Ilmiah. J Kesehatan Andalas. 2014; vol 3: 244-47.

14. Fatmawati, A., Soelaeman, M., dan Rafiyah, I. Faktor-Faktor yang Mempengaruhi Tingkat Depresi pada Pasien dengan Penyakit Ginjal Kronik di RSUD Jombang. Medica Majapahit. 2017; 9 (1): 33-9.

15. Sativa, O. Hubungan Tingkat Pendidikan dengan Derajat Depresi Pasien Diabetes Tipe II di RSUD Dr. Rivai Berau Kalimantan Timur. [Skripsi]. Surakarta: Fakultas Kedokteran Universitas Muhammadiyah Surakarta; 2015.

16. Musliamin. Eksistensi Komunitas Lesbian Gay Biseksual Transgender (LGBT) di Kecamatan Kota dalam Kabupaten Bone. J Hukum Keluarga Islam. 2017; 3 (2): 190-3.

17. Palizgir, M., Bakhtiari, M., dan Esteghamati, A. Association of Depression and Anxiety with Diabetes Mellitus Type 2 Concerning Some Sociological Factors. Iran Red Crescent Med J. 2013; 15(8): 644-8.

18. Wahyuningsih, S. Hubungan Faktor Keturunan dengan Kejadian Gangguan Jiwa di Desa Banaran Galur Kulor Progo Yogyakarta. [Skripsi]. Yogyakarta: Fakultas Ilmu Kesehatan Sekolah Tinggi Ilmu Kesehatan 'Aisyiyah; 2015.

19. Yanuar, R. Analisis Faktor yang Berhubungan dengan Kejadian Gangguan Jiwa di Desa Paringan Kecamatan Jenangan Kabupaten Ponorogo. J Keperawatan Jiwa. 2012; 1 (1): 411. 
20. Sadock, B. J. dan Sadock, V. A. Kaplan \& Sadock Buku Ajar Psikiatri Klinis. Jakarta: EGC; 2015.

21. Kircher, J. dan Ahlijah, A. Developing an Understanding of The Experiences of Parents whose Child has Come Out of The Closet. NACSW Convention Proceedings. 2011; $1-21$ 